\title{
THE LIVER IN SECONDARY SYPHILIS CLINICAL, LABORATORY AND HISTOPATHOLOGICAL INVESTIGATION OF 22 PATIENTS WITHOUT JAUNDICE.*
}

\author{
H.C. Hercules, R. Figliuolo, S. Figliuolo
}

\begin{abstract}
22 patients with a history of syphilitic contact, skin lesions and positive serology were evaluated by physical examination, liver function tests and liver biopsy for evidence of hepatic lesions secondary to treponema infection. Only minimal evidences of hepatic damage were revealed by clinical examination and liver function tests. On biopsy 21 cases of NSRH were noted with one case of gran dloma formation. No spirochaetes were found, so these findings could not be attributed to a direct action of the treponema.
\end{abstract}

\section{INTRODUCTION}

Many authors have studied the causal relationship between jaundice, liver lesions and secondary syphilis by means of case reports $1,2,12,17,20,22,30$. Few have studied the liver in early syphilitic patients without jaundice. In these studies some of the cases cited had been admitted to the ward for reasons other than suspected syphilis ${ }^{15,23,26,31}$.

Before the current use of liver biopsy, Irgang ${ }^{9}$ and $\mathrm{Hahn}^{8}$ suggested an underlying hepatitis in secondary syphilis.

Féher et $\mathrm{al}^{6}$ made a systematic investigation of syphilitic patients who had altered liver function tests by means of liver biopsy.

Rajam and Rangiah ${ }^{19}$, Mc Cracken et al $^{15}$ and now Sherlock ${ }^{24}$ suggested a liver investigation by needle biopsy in early syphilitic patients without clinical nor laboratory evidence of hepatic lesion.

The authors studied 22 volunteers with secondary syphilis using liver function tests and needle biopsy.

\section{MATERIAL AND METHODS}

22 patiens were selected for this study. They all related a history of syphilitic contact and showed secondary syphilitic skin lesions. None of them related excessive use of alcohol and none had any hepatic symptomatology. Of them 12 were women. Their ages ranged between 18 and 43 years. The time between onset of symptoms of secondary syphilis and needle biopsy varied from 4 to 90 days.

Each patient had at least two different serologically positive tests for syphilis (VDRL. Kahn and Maltaner).

The liver function tests performed were: bilirubin, alkaline serum phosphatase, glutamic pyruvate transaminase (SGPT), cholesterol serum proteins (total, fractioned and electrophoresis), flocculation reactions and prothrombin activity.

All patients had a needle biopsy done, after which they were treated with penicillin.

All biopsy specimens were wholly or partially fixed in formaldehyde $4 \%$ and paraffin embedded. The sections were stained by routine HE, PAS, delayed ZiehtNeelsen for ceroid pigment (Scheuer, 1968) and afterwards by the Warthin-Faulkner technique for treponema detection ${ }^{5}$. A specimen from congenital renal syphilis was included in each battery of slides as a positive reference rich in treponemes.

* Hospital Escola São Francisco de Assis, Departaments of Pathology and Internal Medicine, Faculty of Medicine, Federal University at Rio de Janeiro, Correspondence to Dr. H.C. Hercules, Laboratório de Patologia, Hospital Universitário, llha do Fundăo, Rio de Janeiro.

Submitted to publication on June, 1977. 


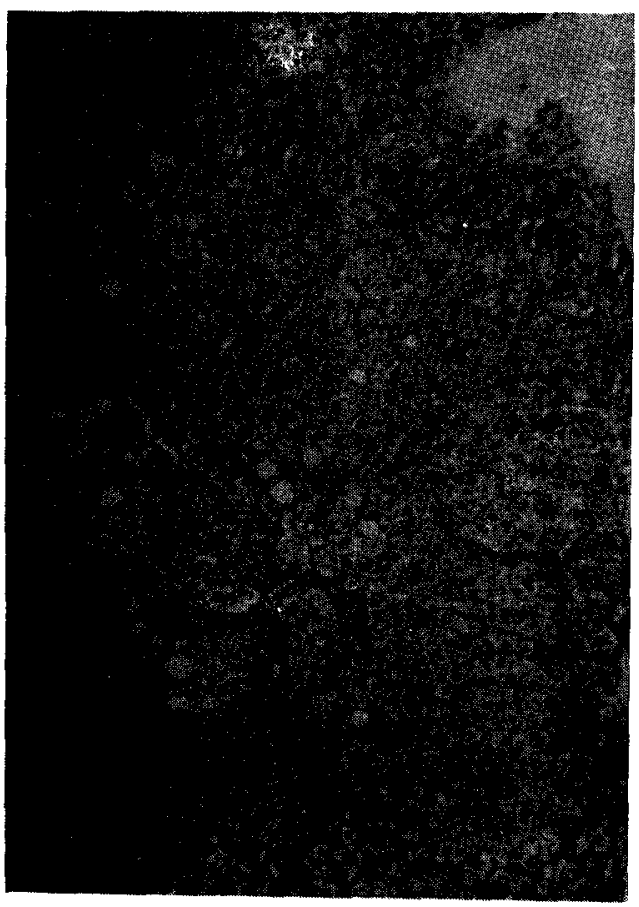

Fig 1 - Portal and intralobular infiltration mostly by mononuclear cells. There is Kupffer cell hyperplasia. Case B-5431 HE. Ob. $10 x$.

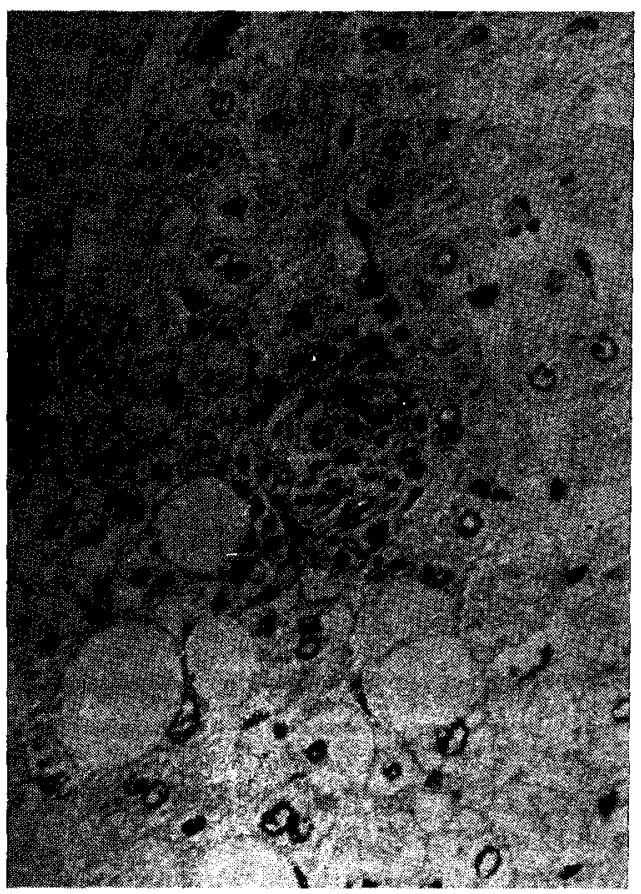

Fig. 3-Focal Iyric necrusis of some hepatocytes with exsudative reaction. Some liver cells show fatty degenetation. Same case as fig.

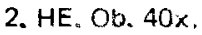

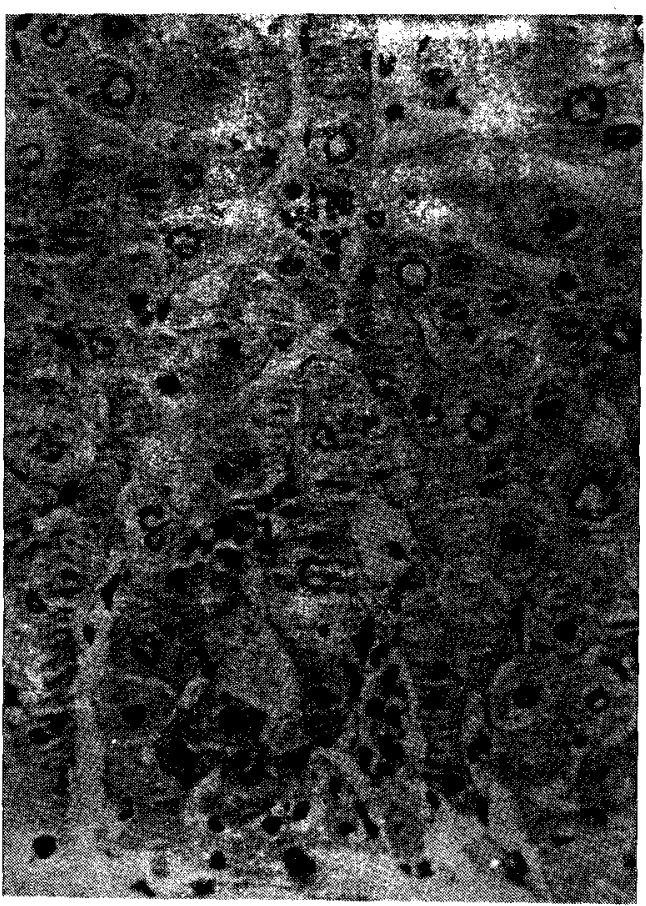

Fig. 2 - Some hepatocytes were substituted by inflamatory cells. Case B-4561. HE. Ob. $40 x$.

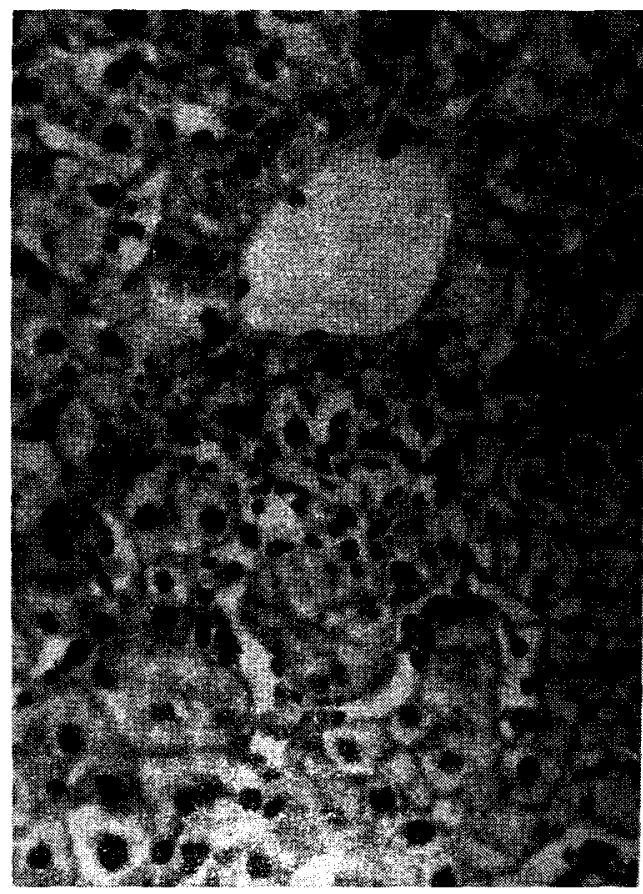

Fig. 4 - Necioili focus near central canal. The exsudative reaction is more pronounced than in fig. 3. Case B-5431. HE. Ob. 40x. 


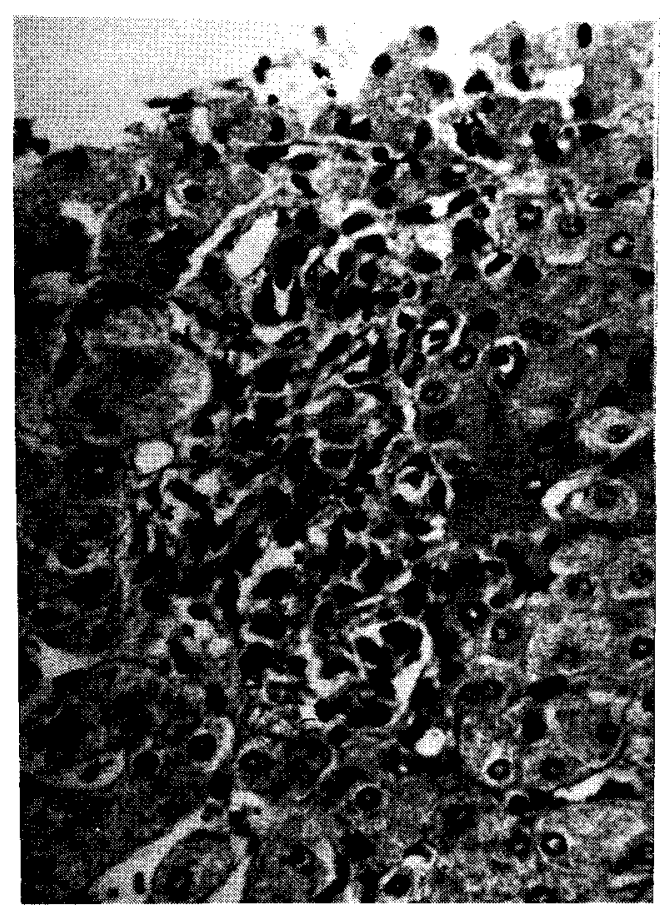

Fig. 5 - Eariy tuberculoid granuloma beside a portal tract. Case B-4566. HE. Ob. $40 x$.

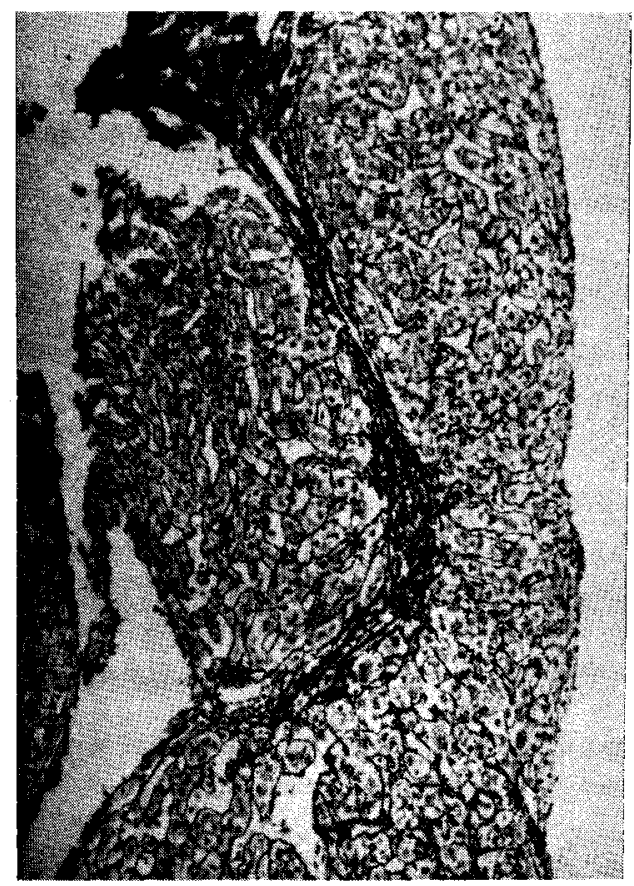

Fig. 7 - Portal enlargement by inflammation and active septum formation. Case B-4580. Silver impregnation apud Wilder. Ob. 10x.

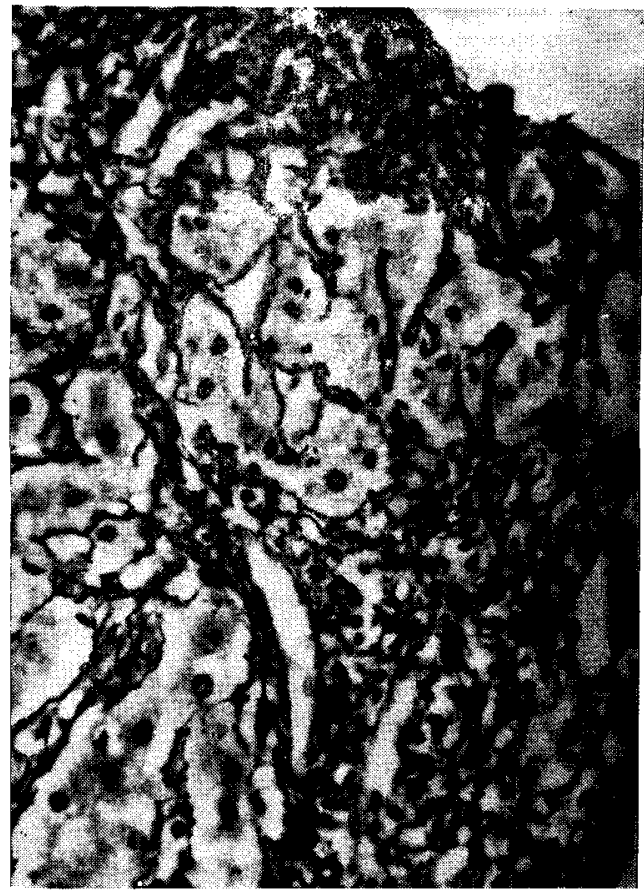

Fig. 6 - Diffuse intralobular infiltration by neutrophils and mononuclear cells. Same case as fig. 1. HE. Ob. $40 x$.

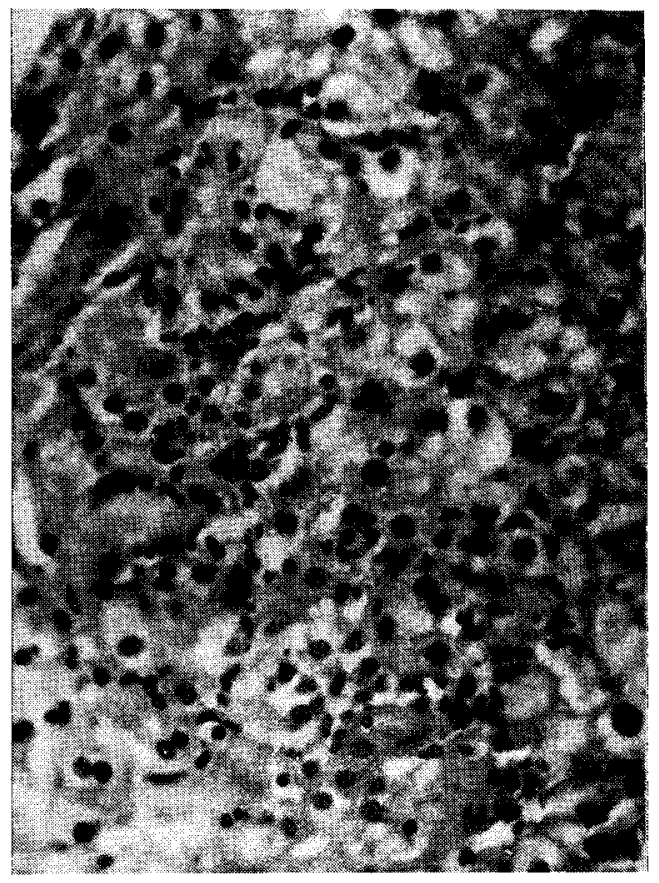

Fig. 8 - Piece-mea! necrosis in same case as fig. 7 . Wilder. Ob. $40 x$. 
Table 1

\begin{tabular}{|c|c|c|c|c|c|c|c|c|c|c|c|c|c|c|c|c|c|c|c|c|c|}
\hline Sex & $F$ & $F$ & $\mathbf{M}$ & $M$ & $F$ & $F$ & $F$ & $M$ & $F$ & $\mathbf{M}$ & $M$ & $M$ & $M$ & $F$ & $F$ & $F$ & $M$ & $M$ & $\mathbf{F}$ & $F$ & $F$ \\
\hline Age & 24 & 30 & 23 & 43 & 39 & 22 & 40 & 19 & 24 & 26 & 30 & 29 & 27 & 22 & 18 & 37 & 32 & 22 & 23 & 31 & 23 \\
\hline Liver & $N$ & $\mathbf{N}$ & $T$ & $\mathbf{N}$ & $\mathbf{N}$ & $\mathbf{N}$ & $N$ & $\mathbf{N}$ & $\mathbf{N}$ & $\mathbf{N}$ & $\mathbf{N}$ & $N$ & $\mathbf{N}$ & $N$ & $\mathbf{N}$ & $N$ & $\uparrow T$ & $\mathbf{N}$ & $\uparrow T$ & $\uparrow$ & $\mathbf{N}$ \\
\hline SGPT & 78 & 30 & 57 & & 24 & 60 & +4 & 60 & 16 & 44 & & 24 & 24 & 60 & & 72 & 36 & 60 & 30 & 36 & 54 \\
\hline $\mathrm{CC}$ & ++ & ++ & + & & $++t$ & + & $+t$ & + & - & ++ & & + & + & ++ & - & ++ & + & - & +++ & + & + \\
\hline$\pi$ & 7.1 & 8.9 & 3.9 & & 13.6 & 9.6 & 6.1 & 4.8 & 3.9 & 7.8 & & 4.1 & 3.6 & 6.9 & 1.9 & & 6.6 & 1.0 & 8.4 & 8.6 & 4 \\
\hline$T F$ & + & ++ & - & & $+t$ & + & + & - & - & ++ & & - & - & + & - & & + & - & ++ & + & - \\
\hline $\mathrm{ZnSO}_{4}$ & 16 & 21 & 12.2 & & 17.5 & 15.6 & 9.1 & 5.6 & 13.7 & 16.9 & & 12.6 & 7.1 & 10.7 & 5.2 & & 12.6 & 5.0 & 14 & 13.2 & 10.0 \\
\hline Alb. & & 3.27 & 2.84 & & & 2.65 & 3.7 & & & 2.26 & 2.23 & 3.38 & & & 2.87 & & 2.44 & 3.04 & 3.7 & 2.96 & 4.4 \\
\hline$\alpha_{1}$ & & 0.22 & 0.21 & & & 0.32 & 1 & & & 0.2 & 0.56 & 0.16 & & & 0.72 & & 0.57 & 0.2 & i & 0.48 & 1 \\
\hline$\alpha_{2}$ & & 0.44 & 0.73 & & & 0.89 & ? & & & 0.47 & 1.0 & 0.8 & & & 0.79 & & 0.72 & 0.51 & 8 & 0.98 & : \\
\hline$\beta$ & & 0.65 & 0.93 & & & 1.02 & $\sim$ & & & 0.39 & 0.76 & 0.64 & & & 0.82 & & 1.1 & 0.62 & N & 0.98 & N \\
\hline $\boldsymbol{\gamma}^{\prime}$ & & 2.32 & 1.78 & & & 1.92 & 1 & & & 1.17 & 1.72 & 1.46 & & & 1.83 & & 1.83 & 1.11 & 1 & 1.63 & 1 \\
\hline Others & $\begin{array}{l}\text { ANF } \\
\operatorname{Ig} G \mid \uparrow\end{array}$ & + & $c \downarrow$ & & & & & & $\operatorname{Ig} M \uparrow$ & & & $c \downarrow$ & & & & & & $\lg M \downarrow$ & & & \\
\hline Size & B & B & B & 8 & $M$ & B & B & B & $S$ & B & $s$ & $\mathbf{M}$ & $M$ & B & M & $\mathbf{M}$ & $\mathbf{S}$ & B & $\mathbf{S}$ & $\mathbf{S}$ & $M$ \\
\hline NSAH & Inten & & & & & Mode & rote & & & & & & & & Light & & & & & & \\
\hline
\end{tabular}

$N=$ normalt $T=$ tendar; $\uparrow=$ pelpated; $\downarrow=$ reduced; $C=$ complement; $A N F=$ antinuclear factor; $B=$ big; $M=$ medium; $S=$ short; (size of specimen) 
One specimen was submitted to silver impregnation as described by Wilder ${ }^{28}$ and studied for the presence of $\mathrm{HB}_{\mathrm{s}} \mathrm{Ag}_{\mathrm{g}}$ according to the Shikata method ${ }^{25}$. Five biopsies were searched for immunoglobulins and $\mathrm{C}^{\prime} 3$ by immunofluorescence of deep frozen sections. One of these five cases was searched for treponemes according to the Levaditi technique ${ }^{13}$.

The diagnosis of nonspecific reactive hepatitis was based on Popper's criteria ${ }^{18}$. According to the intensity of the structural alterations the cases were divided in light, moderate, or intense hepatitis after two random checks.

The liver fragments were classified as small (under $0,5 \mathrm{~cm}$ ), medium 10,6 to $1,0 \mathrm{~cm})$, or big $($ more than $1,0 \mathrm{~cm}$ ) in order to check the validity of the results.

\section{RESULTS}

The most frequent skin lesions were generalized papular syphilids. One case showed papulosquamous syphilids and another showed disseminated alopecia. All cases showed lymph glands enlargment, mostly in the cervical and axillary regions. Of 17 patients, the liver could be palpated but none was considered to be increased in size. Three patients experienced pain on palpation. The spleen was palpated in two patients.

Some liver function tests showed alterations (table 1 ) and the others were within normal range.

21 biopsy fragments showed a nonspecific reactive hepatitis. The bigger specimens (10 in all) revealed more inflammation and necrotic foci than the smaller ones (5 out of 21). Since infiltration of varied intensity was encountered in the portal tracts and less pronounced in the sinusoids the diffuse character of the inflammation was assumed (fig. 1). Infiltration in the portal tracts was the only finding in some cases. The infiltration was mostly by mononuclear cells and to a lesser extent by neutrophils Kupffer cells always were found increased in number and size, sometimes loaded with ceroid pigment.

In 13, inflammatory cells substituting hepatocytes were noted (fig. 2). All these cases showed somewhat different aspects resembling the evolutive stages of the hepatic focal lesion. Less advanced lesions showed one to three hepatocytes with shrunken and acidophilic cytoplasm and the presence of hystiocytes and lymphocytes. In moderately advanced lesions these hepatocytes disappeared and were substituted by hystiocytes, lymphocytes and sometimes by neutrophils (fig 3). Advanced lesions tended to form granuloma (fig. 4 e 5) without any preferential localization in the hepatic lobule. Hepatocytes at a distance from these lesions did not show much evidence of alteration. Some of them were vacuolized with some degree of ballooning but there was no modification in the normal anatomic structure.

One specimen showed an area of intense intralobular infiltration with mostly neutrophils (fig. 6). Another revealed very small acidophilic inclusions in the cytoplasm of the hepatocytes. In one case biopsied 30 days after onset of the disease an intense enlargment of the portal tracts by mononuclear infiltration and piece-meal necrosis could be observed (fig. 7 e 8). The hepatocytes seemed more swollen than in the other cases, but $\mathrm{HB}_{s} \mathrm{Ag}_{\mathrm{g}}$ could not be traced by the Shikata method. No focal lesions were encountered in this case.

Treponemes were not traced by either the Warthir-Faulkner or Levaditi techniques, although all reference slides showed plenty of treponemes.

No immunoglobulins or $\mathrm{C}^{\prime 3}$ could be traced by immunofluorescence.

\section{DISCUSSION}

The liver alterations found in this study were those of nonspecific reactive hepat it is (NSRH). The incidence of NSRH in the whole population is not well known. Out of 3800 biopsies, Meister ${ }^{16}$ found 555 cases and added that NSRH might only be an aspect of hepatitis with a granulomatous reaction. He suggests that the needle might not have reached the granulomas. The use of serial sections might improve the chances of finding them ${ }^{4}$.

The presence of granuloma in luetic lesions was judged to be more typical of the late stage of the disease. The only findings recorded in early stages were lymphoplasmocitary infiltration and capillary proliferation ${ }^{3,19}$. More recent studies have, however, shown that in fact granuloma do occur in the early stayes ${ }^{10}$. 
Many authors failed to find evidence of granuloma formation in the hepatitis of secondary syphilis $1,2,4,7,12,15,17,20$, $22,23,26,30,31$, but Wagoner ${ }^{27}$ in a series of 1100 random liver biopsies found 5 cases of syphilis with granulomatous lesions of which 4 were in the early stage of the disease. Our study revealed granuloma formation only in one case. This does not exclude more cases if the liver fragments could have been larger.

The finding of NSRH in almost all our cases might represent only the hepatic component of a systemic disease, since in none could treponemes be found. This should not be due to technical failure since test sections always were found positive. The 5 cases studied by immunofluorescence did not reveal any lg. Yobs $^{29}$ using a similar method demonstrated Ig captured on treponemes in syphilitic skin lesions. In another study not yet published ${ }^{7}$ one of us also examined liver fragments from 3 icteric patients with secondary syphilis and none revealed the presence of the spirochaetes. Féher et al ${ }^{6}$ on the other hand encountered 7 out of 15 with treponemes in secondary syphilis, Biopsies done after treatment did not reveal any spirochaetes in these patients. Since we and many others authors have not found treponemes in the liver we are not able to ascribe the lesions found in our study to the treponemes.

This type of hepatitis seems to cure without sequelae.

In one of our cases, biopsied 30 days after the onset of skin lesions, we found chronic hepatitis with piece-meal necrosis. The immunoglobulins were not altered and $\mathrm{HB}_{s} \mathrm{Ag}$ was not encountered. Féher et $\mathrm{al}^{6}$ described a similar case but with altered immunoglobulins levels. Finally, we did not find any relationship between the intensity of the lesions, the time of disease and the liver function tests.

\section{REFERENCES}

1. ALBERTAZZI, F.. STRANI, G.F., \& SARTORIS, S. L'epatiti luetica secondaria. Considerazioni cliniche e patogenetiche e presentazione di un caso. G. Ital. dermatol., 45, 440-445, 1970.

2. BAKER, A.L., KAPLAN, M.M. WOLFE, H.J., \& MCGOWAN, J.A. Liver disease associated with early syphilis. $N$. Engl. I. Med., 284, 1422-1423, 1971.

3. BOGLIOLO, L. Inflamações granulomatosas, in "Patologia". Bogliolo, L., $2^{\text {nd }}$ edition, Guanabara Koogan, Rio de Janeiro, pg. 123, 1976.

4. FAUCI, A.S. \& WOLFF, S.M. Granulomatous Hepatitis, in Progress in Liver Diseases, vol. $V$, POPPER, $H$. and SCHAFFNER, F., Grune and Stratton, New York; 1976.

5. FAULKNER, R.R. \& LILLIE, R.D. A buffer modification of the WarthinStarry silver method for spirochaetes in single paraffin sections. Stain Technol., 20,8182, 1945.

6. FEEHER, L, SOMOGYI, T., TIMMER, M.. \& JOZSA, L Early Syphilitic hepatitis Lancet, 2, 896-899, 1975.

7. FIGLIUOLO, R. $O$ fígado na sifilis recente. Thesis to the Course for Master in Gastroenterology from the School of
Medicine of the Federal University at Rio de taneiro, 1976.

8. HAHN, R.D. Syphilis of the liver. Am. J. Syph. Gonor. and Vener. Dis., 27. 529-562, 1943.

9. IRGANG, S. The problem of involvement of the liver in syphilis. Comment on its more important phases with case reports. Arch. Dermat. Syph., 36. 685-708, 1937.

10. KAHN. L.B. \& GORDON, W. Sarcoidlike granulomas in secondary syphilis. A clinical and histopathologic study of five cases. Arch. Path., 92, 334-337, 1971.

11. LANTIS, LR., PETROZZI, J.W., \& HURLEY, H.L Sarcoid granuloma in secondary syphilis. Arch., Derm., 99. 748-752, 1969.

12. LEE, R.V., THORNTON, G.F., \& CONN, H.O. Liver disease associated with secondary syphilis. N. Engl. J. Med., 284, 1423-1425, 1971.

13. LEVADITI, C. L'histologie pathologique de la syphilis hereditaire dans' ses rapports avec le "spirochaete pallida". Ann. de 1" Inst. Pasteur, 20, 41-68, 1906.

14. LEVER, W. F. Treponemal Diseases, in Histopathology of the Skin, $5^{\text {th }}$ edition, 
Lever, W.F.. LB. Lippincott Company, Philadelphia pg. 298-306, 1975.

15 MC CRACKEN, 1.D., HALL, W.H., \& PIERCE, H.I. Nephrotic syndrome and acute hepatitis in secondary syphilis. Milit. Med., 143, 682-686, 1969.

16. MEISTER, P. Die unspezifische (reaktive) Hepatitis. (Morphologische Definition und klinische Bedeutung). Verh. Deutsch. Ges. Path. 53, s10-316. 1969.

17. PARKER, J.D. J Uncommon complications of early syphilis. Hepatitis, po riost it is, iritis with papillitis and meningit is. Br. J. Vener. Dis., 48, 32-36, 1972.

18. POPPER, $H$. and SCHAFFNER, $F$. Nonspecific reactive hepatitis, in Toxic hepatic injury, in Liver: Structure and Function, Blakiston Division, Mc GrawHill Book Company, Inc., New York, pg. 404-407, 1957.

19. RAJAM, R.V. \& RANGIAH, P.N. Early syphilitic hepatitis. Indian J. Vener. Dis. and Derm., 20, 83-94, 1954

20. SARKANI, I. Pruritus and cholestatic jaundice due to secondary syphilis. Proc. Roy. Soc. Med., 66, 237-238, 1973

21. SCHEUER, P. Techniques, in Liver biopsy interpretation, Baillière, Tindall \& Cassell, London, pg. 4-9, 1968.

22. SEHGAL, V.N. \& REGE, V.L Malignant syphilis and hepatitis. $\mathrm{Br}$. J. Vener. Dis., 50, 237-238, 1974.

23. SEWELL, J. Secondary syphilis and hepatitis. Br. Med. J., 3.; -2, 1975.

24 SHERLOCK, S. The liver in secondary (early) syphilis N. Engl J. Med., 284: 1437-1438, 1971

25. SHIKATA, T., UZAWA, T., YOSHIWARA, N., AKATSUKA, T. \& YAMAZAKI, S. Staining methods of Australia antigen in paraffin section. Detection of cytoplasrnic inclusion bodies. Japan J. Exp. Med., 44: 25-36. 1974.

26. SOBEL, H.d \& WOLF, E.H. Liver involvement in early syphilis. Arch. Pathol., 93: 565-568, 1972.

27. WAGONER, G., ANTON, A.T., GALL, E.A. \& SCHIFF, L. Needle biopsy of the liver. VIII. Experiences with hepatic granulomas. Gastroenterology, 25 : 487-494, 1953.

28. WILDER, H.C. An improved technique for silver impregnation of reticulum fibers. Amer. J. Path., 11: 817-819. 1975.

29. YOBS, A.R., BROWN, L. \& HUNTER, E.E Fluorescent antibody technique in early syphilis. Arch. Path., 7.7: 220-225. 1964.

30. YOUNG, E., BAHR, G., \& WAYE, J.D. The Jarisch-Herxheimer reaction in syphilitic hepatitis. Am. J. Gastroenterol., 61: 476-477, 1974.

31. ZELLMANN, H.E. \& NORCROSS, J.W. Early svphilitic hepatitis. Lah. Clin. Found. Bull., 16:255-259, 1967. 